\title{
VALIDITAS PREDIKTIF TES UPCM DENGAN PRESTASI BELAJAR MAHASISWA FAKULTAS PSIKOLOGI UII ANG KATAN 2000
}

\author{
Mira Aliza Rachmawati
}

\begin{abstract}
Abstrak
Penelitian ini bertujuan untuk mengetahui bahwa tes UPCM mampu memprediksi prestasi belajar mahasiswa fakultas Psikologi UII angkatan 2000.

Subyek penelitian yang digunakan dalam penelitian in adalah mahasiswa Fakultas Psikologi UII angkatan 2000 sebanyak 178 subyek yang memenuhi syarat sebanyak 170 . Cara pengambilan datanya dengan menggunakan metode dokumentasi yang diperoleh dari PUSKOM UII untuk UPCM sedangkan IPK diperoleh dari Bagian Akademik Fakultas Psikologi UII.

Teknik analisis yang digunakan adalah dengan menggunakan korelasi product moment dar Pearson. Hasil yang diperoleh adalah antara total UPCM dengan IPK Ganjil diperoleh koefisien korelasi sebesar $r=0,268$ sedangkan koefisien korelasi antara total UPCM dengan IPK Genap sebesar $r=0,263$, koefisien korelasi yang diperoleh kurang dari 0,30. Hal ini menunjukkan suatu hasil yang tidak memuaskan karena koefisien korelasi yang dianggap memuaskan apabila lebih dari 0,30 (Azwar, 2000).
\end{abstract}

Kata kunci : Prestasi Belajar, UPCM, Validitas Prediktif

\section{A PENGANTAR}

Memasuki era globalisasi ini membawa tantangan yang berat bagi bangsa Indonesia, khususnya dalam sektor keja. Masa depan para tenaga keja pada era ini mendapat tantangan yang sangat bera jika dibandingkan pada tahun 1970-an karena pada hakikatnya mereka akan menjadi angkatan kerja di abad ke21 yang penuh dengan persaingan global sehingga mereka harus bersaing dalam skala internasional (Suyanto \& Hisyam, 2000), sebab pada era globalisasi ini tenaga kerja asing bisa masuk ke negara Indonesia dengan bebas dan menempati sektor-sektor kerja yang seharusnya ditempati oleh anak bangsa.

Akibatnya tenaga kerja Indonesia harus mampu bersaing dengan tenaga kerja asing di era globalisasi ini. Agar tenaga kerja Indonesia mampu bersaing dengantenaga keja asing maka dibutuhkan sumber daya manusia yang handal yang mempunyai kemampuar/keahlian dalam bidangnya. Berdasarkan data yang diperoleh dari World Competitiveness Reportahun 1996 (dalam Hamid, 1997) peringkat daya saing sumber daya manusia Indonesia dari 46 negara yang 
disurvei oleh WCR berada pada peringkat yang sangat rendah yaitu berada pada peringkat ke-45. $\mathrm{Hal}$ ini menunjukkan bahwa Indonesia memiliki SDM yang belum handal dan belum kompetitif.

Salah satu hal yang paling penting dalam menentukan kualitas sumber daya manusia adalah pendidikan. Berdasarkan data, kualitas SDM yang dimiliki oleh bangsa Indonesia paling besar didominasi oleh tamatan Sekolah Dasar yaitu sekitar $30 \%$, tidak tamat Sekolah Dasar sekitar $25 \%$, kemudian yang tidak sekolah mencapai $13 \%$, sedangkan tamatan perguruan tinggi dan diploma hanya sekitar 1,5\% (www nakertrans.go.id). Berdasarkan data tersebut terbukti bahwa lulusan dari perguruan tinggi di Indonesia masih sedikit. Fungsi dari sebuah perguruan tinggi adalah sebagai tempat untuk melahirkan intelektual yang mampu menylapkan sumber daya manusia yang baik dan mampu untuk terjun di tengahtengah masyarakat, untuk mengabdi dan mengembangkan ilmu yang telah diperoleh di bangku kuliah (Ahmadi dan Supriyono, 1991). Berdasarkan asumsi tersebut maka sebenarnya lulusan perguruan tinggi sangat dibutuhkan karena mereka dianggap mampu untuk bersaing dengan tenaga kerja asing dalam menempati posisi kerja tertentu.

Oleh karena itu salah satu hal yang sangat menentukan kualitas sumber daya manusia adalah mutu pendidikan, karena mutu pendidikan yang handal memiliki kesanggupan untuk memberdayakan SDM (Wahab, 1997). Faktorfaktor yang mampu untuk meningkatkan mutu pendidikan dimulai dari sarana penunjang pendidikan maupun prasarana pendidikan seperti ruang kuliah yang representatif, fasilitas laboratorium yang lengkap sehingga mahasiswa mempunyai lebih banyak pengalaman praktek, perpustakaan dengan literatur yang memadai serta dilengkapi dengan fasilitas internet maupun intranet, ruang diskusi, biro konseling, poliklinik dan fasilitas-fasilitas lainnnya.

Hal lain yang digunakan sebagai tolok ukur untuk menentukan mutu pendidikan sebuah perguruan tinggi selain yang telah disebutkan d atas adalah prestasi belajar. Prestasi belajar digunakan untuk menentukan apakah seorang mahasiswa telah berhasil dalam mencapai tujuan yang ditetapkan dalam sebuah program pendidikan (Syah, 2003) sehingga prestasi belajar sebagai salah satu indikator penting yang digunakan untuk menentukan keberhasilan proses belajar seorang mahasiswa.

Prestasi belajar menurut Kamus Besar Bahasa Indonesia (www. bpkpenabur.com) adalah penguasaan pengetahuan/ketrampilan yang dikembangkan oleh mata pelajaran. Prestasi belajar dapat dioperasionalkan dalam bentuk indikator-indikator yang berupa nilai rapor bagi siswa SD, SLTP dan SMU, indeks prestasi studi bagi perguruan tinggi, angka kelulusan, predikat keberhasilan dan semacamnya (Azwar, 1999).

Fenomena yang terjadi pada saat ini banyak sekali mahasiswa yang kurang lancar dalam menyelesaikan studinya, mahasiswa tidak mampu menunjukkan prestasinya secara optimal sesual dengan potensi yang dimiliki. Banyak mahasiswa yang terpaksa harus di DO (drop out) karena indeks prestasi yang dicapai tidak sesuai dengan ketentuan atau peraturan yang berlaku di suatu universitas.

Berdasarkan data yang diperoleh dari Biro Administrasi Akademik dan Kemahasiswaan Universitas Islam 
Indonesia Yogyakarta (Setiawati, 2002) nilai indeks prestasi (IP) mahasiswa UII tahun ajaran 2001/2002 dari program ilmu eksakta memiliki rata-rata sekitar 2,28 dari target IP yang diharapkan yaitu 2,75 dan untuk program ilmu non eksakta memiliki IP rata-rata 2,50 dari target IP yang diharapkan 3,00 . Fakultas Psikologi memiliki $\mathbb{P}$ rata-rata 2,52 dari target $\mathbb{P} 3,00$. Memperhatikan keadaan prestasi belajar mahasiswa tersebut ternyata masih jauh dari harapan.

Melihat keadaan yang memprihatinkan terse but perlu untuk dikaji lebih jauh faktor-faktor yang mempengaruhinya. Salah satu faktor yang penting dan juga menentukan tingkat keberhasilan seorang mahasiswa di perguruan tinggi adalah bagaimana sistem penerimaan mahasiswa baru di perguruan tinggi tersebut. Selama ini sistem penerimaan mahasiswa baru yang digunakan oleh beberapa perguruan tinggi adalah dengan sistem seleksi, yang agak berbeda dengan sistem penerimaan calon siswa di tingkat SD, SLTP maupun SMU. Penerimaan calon siswa di tingkat SD, SLTP maupun SMU meskipunjuga menggunakan sistem seieksi yaitu mempertimbangkan hasil tes ujian masuk tetapijuga memperhitungkan nilai ujian akhir di tingkat sebelumnya, sedangkan di perguruan tinggi adalah murni seleksi dengan menggunakan sistem ujian masuk tanpa memperhitungkan hal-hal lainnya.

Berdasarkan hal tersebut maka perlu lebih diperjelas lagi bahwa proses seleksi penerimaan mahasiswa baru harus dengan menggunakan sistem yang baik dan prosedur yang baik pula karena dengan baiknya proses tersebut, maka perguruan tinggi mampu mengidentifikasi calon mahasiswa yang benar-benar memiliki potensi yang baik sehingga harapannya adalah calon mahasiswa tersebut mampu menempuh pendidikan di tingkat tinggi dengan baik pula, oleh sebab itu alat yang digunakan sebagai tes seleksi tersebut harus benar-benar baik sehingga benar-benar mampu membedakan calon mahasiswa yang potensial dan tidak potensial (Safitri, 2002).

Seleksi penerimaan mahasiswa baru d lingkungan Universitas Islam Indonesia dengan menggunakan seleksi model UPCM yaitu Ujian Potensi Calon Mahasiswa, yang berbeda dengan seleksi penerimaan mahasiswa baru model perguruan tinggi negeri. Letak perbedaannya adalah pada materi yang diujikan, dimana materi ujian untuk perguruan tinggi negeri adalah materi dasar seperti PPKN, bahasa Indonesia, Matematika dan bahasa Inggris serta materi sesuai dengan bidang ilmu yaitu materi untuk ilmu pengetahuan sosial (IPS) atau ilmu pengetahuan alam (IPA) yang dikenal dengan SPMB (Sistem Penerimaan Mahasiswa Baru) menggantikan istilah UMPTN (Ujian Masuk Perguruan Tinggi Negeri), sedangkan materi ujian di Universitas Isiam Indonesia adalah Agama Islam, Bahasa inggris, Penalaran Logika, Penalaran Analitik serta Aritmatika dan dikenal dengan istilah UPCM. Perbedaan yang lain adalah waktu yang dibutuhkan untuk mengerjakan materi ujian tersebut, dimana untuk SPMB membutuhkan waktu sama halnya dengan ulangan di tingkat SMU sedangkan untuk UPCM masing-masing materi yang terdiri dari 40 soal membutuhkan waktu pengerjaan sekitar 40 menit, sehingga total waktu yang digunakan untuk mengerjakan lima materi dimana masing-masing materi 40 soal adalah sekitar 200 menit, oleh 
karena itu calon mahasiswa dituntut agar cepat dalam mengerjakannya.

Prinsip dasar Universitas Islam Indonesia memberlakukan tes UPCM adalah berfungsi sebagai upaya untuk mencari dan mendapatkan calon mahasiswa yang memiliki potensi akademik yang mendukung tercapainya tujuan UII yaitu peningkatan kualitas komponen input sebagai tujuan umum (Almigo, 2000). Sedangkan tujuan khususnya adalah (Katalog Uil dalam Almigo 2000) :

1. Menjaring calon-calon mahasiswa yang sesuai dengan kualifikasi yang dikehendaki yaitu yang memiliki potensi akademik dan potensi nilairilai spesifik lainnya, yang diperkirakan akan mampu menyelesaikan studi dalam waktu normal.

2. Menjaring calon mahasiswa yang berpotensi melalui penerapan pola seleksi ganda, yaitu melalui tes umum dan penelusuran minat dan kemampuan (PMDK) dengan memberikan kesempatan yang merata bagi putra-putri Indonesia sebagai implementasi makna "Indonesia" dalam nama UII.

Berdasarkan uraian di atas dapat disimpulkan bahwa UPCM dapat digunakan untuk memprediksikan tingkat keberhasilan calon mahasiswa dalam menjalankan studinya d perguruan tinggi, sehingga timbul suatu pertanyaan penelitian apakah tes UPCM mampu memprediksi keberhasilan belajar mahasiswa fakultas Psikologi UnI angkatan 2000 ?

\section{B. TINJAUAN PUSTAKA}

Prestasi Belajar. Menurut Slavin (1991) belajar adalah perubahan yang terjadi pada individu karena adanya pengalaman. Belajar menurut Slameto (dalam Djamarah, 2002) adalah suatu proses usaha yang dilakukan individu untuk memperoleh suatu perubahan tingkah laku yang baru secara keseluruhan, sebagai hasil pengalaman individu itu sendiri dalam interaksinya dengan lingkungannya.

Menurut Gage and Berlinger (1998) belajar adalah proses dimana berubahnya perilaku individu sebagai hasil dari pengalaman. Belajar menurut pendapat Djamarah (2002) adalah serangkaian kegiatan jiwa raga untuk memperoleh suatu perubahan tingkah laku sebagai hasil dari pengalaman individu dalam interaksi dengan lingkungannya yang menyangkut kognitlf, afektif, dan psikomotor.

Belajar dalam pengertian umum sebagaimana yang diungkapkan oleh Azwar (1999) adalah setiap perubahan perilaku yang diakibatkan pengalaman sebagai hasil interaksi individu dengan lingkungannya, sedangkan dalam artian yang spesifik masih menurut Azwar belajar adalah akuisisi atau perolehan pengetahuan dan kecakapan baru. Pendapat lain dikemukakan oieh Syah (2002) belajar adalah taha pan perubahan seluruh tingkah laku individu yang relatif menetap sebagai hasil pengalaman dan interaksi dengan lingkungannya yang melibatkan proses kognitif

Agar bisa mengetahui seberapa jauh seorang indlvidu tersebut mampu menguasai suatu mata pelajaran tertentu, maka diperiukan suatu hasil. Oleh karena itu dalam belajar tidak akan terlepas dari hasil belajar, karena dengan hasil belajar tersebut para guru blsa mengetahui seberapajauh materi-materi yang sudah diberikan tersebut mampu dipahami oleh anak didiknya, sedangkan bagi anak didik dapat mengetahui seberapa jauh kemampuan yang dimiliki oleh dirinya. 
Prestasi belajar menurut Wirawan (dalam Alsa dan Hardjito, 1990) adalah hasil belajar yang diperoleh mahasiswa selama periode waktu tertentu, yang dinyatakan dalam simbol huruf atau bilangan, seperti yang tercantum dalam rapot. Prestasi belajar untuk tingkat perguruan tinggi berdasarkan indeks prestasi yang diperoleh mahasiswa dalam kurun waktu satu semester yang disebut dengan Indeks Prestasi Semester (IPS) dan hasil kumulatif dari beberapa semester yang disebut dengan Indeks Prestasi Kumulatif (IPK).

Nilai IPK yang berlaku di perguruan tinggi bergerak dari 0,0 sampai dengan 4,0. Semakin besar nilai IPK yang diperoleh individu maka semakin tinggi prestasi belajarnya dan sebaliknya semakin rendah nilai IPK maka semakin rendah prestasi belajamya (Fahmie dan Kumiawan, 2003)

Mengetahui IPK dari seseorang dengan menggunakan rumus (Katalog UII, 1997):

IPK Kumulatif =

Jumlah hasil kali SKS yang diambil dengan mas|ngmasing nilai bobotnya

Jumlah SKS yang tolah dikumpulkan

Faktor-faktor yang Mempengaruhi Prestasi Belajar. Ada beberapa faktoryang mempengaruhi tingkat keberhasilan seorang siswa dalam belajar. Menurut Djamarah (2002) faktor-faktor yang mempengaruhi seseorang tersebut berhasil dalam belajar terbagi menjadi faktor dari luar dan faktor dari dalam individu. Faktor-faktoryang berasal dari luar adalah

a Faktor Lingkungan

Lingkungan merupakan bagian dari kehidupan seorang individu, karena dengan lingkunganlah manusia dapat hidup dan berinteraksi dalam mata rantai kehidupan yang disebut ekosistem. Terbagi menjadi :

1. LingkunganAlami, merupakan lingkungan dimana manusia hid $u$

2. Lingkungan Sosial Budaya, manusia membutuhkan hidup bersama satu sama lain

b. Faktor Instrumental

Merupakan kelengkapan yang ada pada setiap lembaga pendidikan, termasuk disini adalah :

1. Kurikulum, merupakan a plan for learning yang merupakan unsur substansial dalam pendidikan. Tanpa kurikulum, kegiatan belajar mengajar tidak dapat berlangsung.

2. Program Pendidikan, disusun dan dijalankan demi kemajuan pendidikan

3. Sarana dan fasilitas,

4. Guru/dosen

Faktor-faktoryang berasal dari dalam invidu adalah :

a Fisiologis

1. Kondisi Fisiologis

2 Kondisi Panca Indra

b. Psikologis

1. Minat

2 Kecerdasan

3. Bakat

4. Motivasi

5. Kemampuan kognitif

Menurut Azwar (1999), faktor-faktor yang mempengaruhì seorang mahasiswa dapat berhasil dalam belajar adalah :

a. Faktor Intemal, terbagi menjadi

1. Fisik
a Panca Indra
b. Kondisi Fisik Umum

2. Psikologis
a. Variabel Non Kognitif
1. Minat 
2. Motivasi

3. Variabel-variabel Kepribadian

b. Kemampuan Kognitif

2 Kemampuan Khusus (Bakat)

3. Kemampuan Umum (Inteligensi)

b. Faktor Ekstemal

1. Fisik

a. Kondisi Tempat Belajar

b. Sarana dan Perlengkapan Belajar

c. Materi Pelajaran

d. Kondisi Lingkungan Belajar

2. Sosial
a. Dukungan Sosial
b. Pengaruh Budaya

Berdasarkan berbagai pend apat diatas dapat disimpulkan bahwa faktor-faktor yang mempengaruhi prestasi belajar seorang mahasiswa bisa digolongkan menjadi dua yaitu faktor intemal dan faktor eksternal.

Ujian Potensi Calon Mahasiswa. Sistem seleksi penerimaan mahasiswa baru di Universitas Islam Indonesia menggunakan tes yang berbentuk speed test. Istilah yang dipakai adalah Ujian Potensi Calon Mahasiswa (UPCM).

Tes UPCM yang dipakai sampai dengan sekarang ini merupakan ide dari Dekan Fakultas Psikologi ter dahulu yaitu DjamaludinAncok, Ph.D, dimana menunut Ancok ada dua hal yang bisa diungkap dengan menggunakan tes ini (Almigo, 2000) yaitu :

a AspekAkademik

Tes UPCM mampu mengungkap faktor $G$ yaitu General merupakan prinsip umum yang mengungkap kernampuan secara general, termasuk memahami prinsip-prinsip dan instruksi yang berlaku, melakukan penalaran dan pertimbangan.

b. Aspek Non Akademik

Tes UPCM yang diberlakukan merupakan suatu penghernatan/efisiensi, dalam arti yaitu penghematan waktu dan dana. Tes UPCM yang diberlakukan pada saat dahulu sekitar tahun 1997 hanya membutuhkan waktu 3 jam, sedangkan yang diberlakukan sejak tahun 1999 sampai dengan sekarang membutuhkan waktu sekitar tiga jam 30 menit, tambah waktu 30 menit karena materi yang diujikan lebih banyak daripada sebelumnya. Penghematan lainnya dari segi biaya yang relatif murah dibandingkan tes yang digunakan oleh UII sebelumnya.

Tujuan Menggunakan Sistem Ujian Potensi Calon Mahasiswa. Ujian Potensi Calon Mahasiswa (UPCM) dipakai sejak tahun 1997, ada beberapa tujuan digunakannya sistem seleksi penerimaan mahasiswa baru dengan UPCM yaitu tujuan umum dan tujuan khusus (Katalog UIl, 1997). Tujuan umumnya adalah untuk peningkatan kualitas komponen input. sedangkan tujuan khususnya adalah :

a. Menjaring calon-calon mahasiswa yang sesuai dengan kualifikasi yang dikehendaki yaitu memiliki potensi akademik dan potensi nilai-nilai spesifik lainnya, yang diperkirakan akan mampu menyelesaikan studi dalam waktu normal.

b. Menjaring calon-calon mahasiswa bibit unggul melalui penerapan pola seleksi ganda, yaitu melalui tes umum dan penelusuran minat dan kemampuan (PMDK) dengan memberikan kesempatan yang merata bagi putra-putri Indonesia sebagai implementasi makna "Indonesia" dalam nama UIl.

Komponen Ujian Potensi Calon Mahasiswa. Bahan atau materi yang diujikan dalam soal UPCM tidak kurikuler, karena tidak mengukur kognitif calon mahasiswa tetapi mengukur potensi (Pedoman Umum Penyusunan Soal, 2002). Berdasarkan hal tersebut bahan 
atau materi yang diujikan dalam UPCM meliputi Kemampuan Agama Islam, Kemampuan Bahasa Inggris, Penalaran Logika, Penalaran Analitik, dan Matematika/Anitmatika. Jumlah soal untuk tiap-tiap materi sebesar 40 aitem sehingga jumlah total untuk semua soal sebanyak 200 aitem. Diprediksikan waktu yang dibutuhkan untuk mengerjakan satu soal adalah satu menit sehingga total waktu yang dibutuhkan untuk mengerjakan seluruh komponen soal adalah 200 menit atau 3 jam 20 menit. Cara memberikan skor untuk UPCM adalah jawaban yang benar diberi skor satu (1) sedangkan jawaban yang slah diberi skor nol (0), skor total diperoleh dengan menjumlahkan seluruh jawaban yang benar.

Validitas Prediktif. Validitas adalah sejauhmana kecermatan dan ketepatan alat ukur dalam melaksanakan fungsi ukurnya (Azwar, 1996). Menurut Azwar (1996) validitas terbagi dalam beberapa tipe yaitu validitas isi, validitas konstrak dan validitas berdasar kriteria. Validitas berdasar kriteria masih terbagi lagi menjadi tipe validitas konkuren dan validitas prediktif. Validitas yang dipakai dalam penelitian ini adalah validitas berdasar kriteria yaitu tipe validitas prediktif. Validitas prediktif adalah suatu alat ukur yang digunakan untk memprediksi performansi yang akan datang artinya keberhasilan pada program sebelumnya dapat digunakan untuk menentukan keberhasilan pada program yang selanjutnya. Misalnya UPCM dapat digunakan untuk memprediksi prestasi belajar maha-siswa pada masa yang akan datang. Tinggi rendahnya validitas prediktif ditentukan oleh besarnya hubungan antara skor tes yang diuji disebut prediktor dan performansi yang akan diprediksikan disebut kriteria yang disebut dengan koefisien validitas prediktif (Fahmie dan Kurniawan, 2003). Koefisien validitas prediktif dapat dihitung dengan menggunakan korelasi antara prediktor dengan kriteria. Koefisien validitas yang tinggi mendekati $r=1,00$ tetapi sulit untuk memperoleh hasil sekian. Berdasarkan kesepakatn umum bahwa koefisien validitas dapat dianggap memuaskan apabila melebihi $r=0,30$ (Azwar, 1996).

Validitas Prediktif Nilai UPCM dengan Prestasi Belajar Mahasiswa Fakullas Psikologi UII Angkatan 2000 Ujian Potensi Calon Mahasiswa (UPCM) merupakan salah satu jenis alat tes yang dapat digunakan untuk memprediksi hasil belajar dari seorang mahasiswa di UII. Materi yang diujikan dalam UPCM bukan berbentuk kurikuler seperti yang diajarkan di SMU karena tidak mengukur kognitif saja melainkan materi yang disesuaikan dengan kemampuan Iulusan SMU yang digunakan untuk mengukur potensi dari calon mahasiswa, sehingga melalui tes UPCM inilah paling tidak dapat digunakan untuk memilih calon mahasiswa yang benar-benar potensial dalam bidangnya berdasarkan skor minimal tertentu untuk dapat dinyatakan diterima di UII.

Alat tes UPCM UII mengacu pada alat tes yang digunakan di Amerika dengan pola seleksi menggunakan SAT (Scholastic Aptitude Test) yang pernah diuji tentang validitas prediksinya hanya dua semester untuk mengukur potensi (Almigo, 2000).

Penelitian Almigo (2000) tentang validitas prediksi hasil tes UPCM dan NEM pada Fakultas Psikologi Universitas Islarn Indonesia Angkatan 1997 (lima semester), menunjukkan hasil bahwa secara keseluruhan prediktor UPCM dan NEM menunjukkan daya prediksi yang belum mernuaskan, dengan koefisien 
korelasi UPCM terhadap IPK sebesar r $=0,221$, sedangkan koefisien korelasi NEM terhadap IIPK sebesar $r=0,022$.

Berdasarkan uraian diatas peneliti ingin meneliti kembali tentang validitas prediktif nilai UPCM dengan prestasi belajar mahasiswa Fakultas Psikologi UII angkatan 2000 pada dua semester yaitu semester ganjil dan semester genap.

\section{HIPOTESIS}

Nilai UPCM mampu memprediksi Prestasi Belajar pada Mahasiswa Fakultas Psikologi UH Angkatan 2000.

1. Nilai total UPCM mampu memprediksi IPK Semester Ganjil mahasiswa Fakultas Psikologi Universitas Islam Indonesia.

2. Nilai total UPCM mampu memprediksi IPK Semester Genap mahasiswa Fakultas Psikologi Universitas Islam Indonesia.

3. Nilai tes UPCM materi Agama Islam mampu memprediksi IPK semester Ganjil mahasiswa Fakultas Psikologi UII

4. Nilai tes UPCM materi Agama Islam mampu memprediksi IPK semester Genap mahasiswa Fakultas Psikologi Ull.

5. Nilai tes UPCM materi Penalaran Logika mampu memprediksi IPK semester Ganjil mahasiswa Fakultas Psikologi UII

6. Nilai tes UPCM materi Penalaran Logika mampu memprediksi IPK semester Genap mahasiswa Fakultas Psikologi UII.

7. Nilai tes UPCM materi Penalaran Analitik mampu memprediksi IPK semester Ganjil mahasiswa Fakultas Psikologi UII

8. Nilai tes UPCM materi Penalaran Analitik mampu memprediksi IPK semester Genap mahasiswa Fakultas PsikologiUll.
9. Nilai tes UPCM materi Aritmatika mampu memprediksi IPK semester Ganjil mahasiswa Fakultas

\section{METODE PENELITIAN}

Subjek Penelitian

Subjek penelitian adalah mahasiswa Fakultas Psikologi UII angkatan 2000 yang telah menempuh studi selama empatsemesteryangbejumlah 178orang Metode Pengumpulan Data

Metode pengumpulan data yang dipakai dalam penelitian ini adalah dengan metode dokumentasi. Metode dokumentasi menurut Azwar (2003) merupakan sakah satu cara untuk memperoleh data dari fihak lain dan tidak langsung diperoleh peneliti dari subjek penelitiannya. Data tentang nilai UPCM diperoleh dari PUSKOM UII sedangkan data tentang IPK diperoleh dari Bagian Akademik Fakultas Psikologi UII.

Metode Analisis Data

Metode analisis data yang digunakan dalam penelitian int adalah analisis korelasi product moment dari Pearson dengan bantuan komputer program SPSS versi 11,0 for Windows.

\section{E. HASIL PENELITIAN}

Pengambilan data penelitian dilakukan pada tanggal 31 Agustus 2003, untuk skor UPCM diperoleh dari PUSKOM UII sedangkan data IPK mahasiswa UII diperoleh dari bagian Akademik Fakultas Psikologi UII hanya untuk angkatan 2000 .

Subjek dalam penelitian ini adalah mahasiswa fakultas Psikologi UII angkatan 2000 yang telah menempuh studi selama empat semester sehingga data IIPK yang dipakai dalam penelitian ini adalah IPK semester ganjil tahun akademik 2001/2002 sebanyak 178 mahasiswa dan IPK semester genap 
tahun akademik 2001/2002 sebanyak 173 mahasiswa. Setelah diperiksa dari 178 mahasiswa untuk semester ganjil 2001/2002 yang dapat dianalisis sebanyak 170 , begitu juga dari 173 mahasiswa semester genap 2001/2002 yang dapat dianalisis sebanyak 170 karena ada beberapa mahasiswa yang aktif pada semester ganjil tetapi tidak aktif pada semester genap dan tidak memenuhi persyaratan SKS yang sudah ditempuh.

Penelitian mengenai validitas prediktif tes UPCM dengan prestasi belajar ini dianalisis dengan menggunakan korelasi product moment dari Pearson. Sebelum dilakukan analisis terlebih dahulu dilakukan uji asumsi yang berupa uji normalitas dan uji linieritas.

Uji normalitas dari 170 subjek penelitian dilakukan dengan menggunakan One Sample Kolmogorov Smimov untuk masing-masing variabel.

Tabel 1

Hasil Uj! Asumsi Normalitas

\begin{tabular}{|c|c|c|c|}
\hline Varlabel & skork-sz & $P$ & Keterangan \\
\hline PR Ga्a & 0790 & 0.561 & Nowing \\
\hline Ficenap & 0964 & 0287 & Arrenal \\
\hline 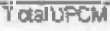 & 0,80 & 0.369 & 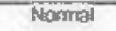 \\
\hline
\end{tabular}

Berdasarkan tabel diatas dapat diketahui bahwa perhitungan Kolmogorov-Smirnov $Z$ (K-SZ) terhadap IPK Ganjil, IPK Genap dan total UPCM diperoleh hasil $p>0,05$ sehingga sehinggaketiga data tersebut mempunyai distribusi normal.

Uji linieritas menggunakan perhitungan statistik program SPSS 11,0 for windows sebagaimana yang tercantum dalam tabel:

\section{Tabel2}

Hasil Uji Linieritas

\begin{tabular}{|c|c|c|c|}
\hline Variatian & 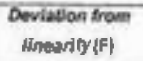 & 7 & Keterning \\
\hline 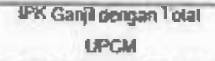 & 0,055 & $0 m$ & Lita \\
\hline 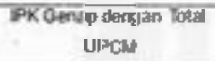 & 0,728 & कल्भा & Liner \\
\hline
\end{tabular}

Berdasarkan tabel diatas dengan menggunakan perhitungan deviation from linearity untuk IPK Ganjil dengan Total UPCM menghasilkan $F=0,835$ dan $p=$ 0,777 sedangkan IPK Genap dengan Total UPCM menghasilkan $F=0,728$ dan $p=$ 0,911 sehingga keduanya mempunyai hubungan linier.

Hasil analisis dengan menggunakan korelasi product moment dari Pearson ditunjukkan pada tabel sebagai berikut:

\begin{tabular}{|c|c|c|c|}
\hline Hriabet & $\mathbf{f}$ & $r$ & $p$ \\
\hline Agana Istam-IFK GanjT & $0,0 \sqrt{3}$ & Duns & 0345 \\
\hline Bethas hoprs 1PK Gorit' & 0,190 & 0035 & OSh4 \\
\hline 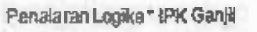 & q120 & 0,100 & 0100 \\
\hline 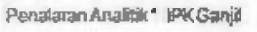 & 0.139 & 0.09 & Qथता \\
\hline Aitmalitad "IPK Gargit & 0,140 & 0,02 & 0,10 \\
\hline TOLI UPCM - PA Gang & 0,259 & $\overline{0,67}$ & $0,0,00$ \\
\hline 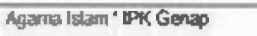 & 4.967 & 0,009 & $\overline{0.62 T}$ \\
\hline Bahzsa hag ir "FK Genap & 0.178 & 0 onsis & 0,002 \\
\hline 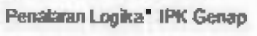 & 0,20 & 0,003 & 0,000 \\
\hline Penalaran Analif "IPK Ganap & 0,364 & 0,000 & 0,033 \\
\hline Antruafilat " IFK Genap & 0.938 & 0,089 & $0,0 \mathrm{2}$ \\
\hline 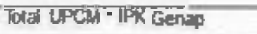 & 0,20 & 0.699 & D.jon \\
\hline
\end{tabular}

Dari hasil anal is is dapat diketahui juga koefisien determinan dari UPCM sebagai variabel bebas sebesar $r^{2}=0,072$ terhadap IPK Ganjil dan $r^{2}=0,069$ terhadap IIPK Genap. Hal ini menunjukkan bahwa UPCM memberikan kontribusi sebesar 7,2 \% terhadap IPK Ganjil dan 6,9\% terhadap IPK Genap.

\section{F. PEMBAHASAN}

Berdasarkan analisis yang telah dilakukan antara tota UPCM dengan IPK Ganjil diperoleh koefisien korelasi sebesar $r=0,268$ sedangkan koefisien korelasi 
antara total UPCM dengan IPK Genap sebesar $r=0,263$, oleh karena itu koefisien korelasi yang dihasilkan kurang dari 0,30 . Hal ini menunjukkan suatu hasil yang tidak memuaskan karena koefisien korelasi yang dianggap memuaskan apabila lebih dari 0,30 (Azwar, 2000). Hal ini dipertegas juga oleh Cronbach (Azwar, 2000) bahwa apabila suatu tes fungsinya untuk memprediksi hasil suatu posedur seleksi maka koefisien korelasinya berkisar antara 0,30 sampai dengan 0,50 .

Hasil yang diperoleh menunjukkan bahwa alat seleksi UPCM belum memuaskan dalam memprediksi indeks prestasi dari mahasiswa. Hal ini disebabkan oleh beberapa faktor, antara lain seleksi dengan menggunakan UPCM merupakan cara menyeleksi calon mahasiswa yang berbeda dengan seleksi SPMB. Perbedaannya terletak pada materi yang diujikan, waktu pengerjaan, serta sistem skoringnya. Materi yang diujikan dalam UPCM bukan berupa mata pelajaran yang pernah diperoleh pada waktu SMU (kurikuler) melainkan suatu materi yang dirancang khusus untuk mengukur potensi dari calon mahasiswa. Waktu yang dibutuhkan untuk mengerjakan sału soal kira-kira satu menit sehingga waktu yang dibutuhkan secara keseluruhan sekitar 200 menit sedangkan sistem skoringnya tidak menggunakan sistem hukuman tetapi bila jawaban benar di beri skor satu sedangkan bila jawaban salah tidak dihukum tetapi diberi skor nol, sehingga kemungkinan calon mahasiswa dalam memberi jawaban hanya semata-mata menebak bukan karena calon mahasiswa tersebut benarbenar mampu dalam mengerjakan. Selan itu masih ada faktor lain yaitu tidak semua materi yang diujikan relevan dengan bidang studi yang akan diambil karena masing-masing fakultas mempunyai passing grade yang berbeda terhadap materi-materi ujian dalam $\mathrm{UPCM}_{\mathrm{r}}$ misalnya agar bisa diterima di fakultas Psikologi maka skor yang diperoleh dalam materi penalaran logika dan bahasa Inggris harus mencapai suatu skor minimal tertentu yang lebih tinggi bila dibandingkan dengan materi agama Islam, penalaran analitik dan aritmatika.

Dari hasil yang diperoleh untuk materi penalaran logika menunjukkan hasil koefisien korelasi sebesar $r=0,326$ terhadap IPK Ganjil dan koefisien sebesar $r=0,288$ terhadap IPK Genap, bila dibandingkan dengan materi ujian UPCM lainnya temyata koefsien korelasinya lebth tinggi. Materi penalaran logika relevan dengan psikologi karena agar dapat belajar di Fakultas Psikologi maka diharapkan mahasiswa mampu berpikir secara logis yang meliputi mampu berpikir secara nalar, mampu menarik suatu kesimpulan terhadap informasi yang ada dan mampu berpikir secara deduktif maupun induktif (Chaplin, 2000).

Disamping penalaran logika, temyata materi bahasa Inggris juga diperoleh hasil koefisien korelasi sebesar $r=0,188$ terhadap IPK Ganjil dan koefisien korelasi sebesar $r=0,175$ terhadap IPK Genap. Dari hasil yang diperoleh ternyata koefisien korelasi bahasa Inggris lebih tinggi dibandingkan koefisien korelasi agama Islam, penalaran analitik, dan aritmatika. Bahasa Inggris dibutuhkan untuk belajardi Fakultas Psikologi karena dalam proses belajar mengajarnya termasuk buku-buku penunjang maupun istilah-istilah yang dipakai dalam psikologi sebagian besar menggunakan istilah bahasa Inggris yang tidak mungkin 
diterjemahkan dalam bahasa Indonesia karena akan mempunyai arti yang berbeda.

Belum memuaskannya hasil yang diperoleh untuk memprediksi prestasi belajar bisa juga disebabkan faktorfaktor lain. Faktor-faktor tersebut antara fain adalah faktor internal maupun faktor eksternal, faktor internal seperti kondisi fisik dan psikis dari mahasiswa misalnya tingkat inteligensi, bakat, minat, motivasi dan sebagainya, sedangkan faktor eksternal adalah faktor fișik dan sosial misalnya sarana dan prasarana.

\section{G. KESIMPULAN DAN SARAN}

Berdasarkan hasil penelitian yang telah dilakukan maka dapat disimpulkan bahwa : tes UPCM belum mampu untuk memprediksi prestasi belajar mahasiswa fakultas Psikologi karena koefisien korelasi yang diperoleh belum memuaskan yaitu sebesar $r=0,268$ terhadap IPK Ganjil dan sebesar $r=0,263$ terhadap IPK Genap.

Bagi peneliti yang tertarik dengan penelitian sejenis, alangkah baiknya menambah variabel lain misalnya tingkat inteligensi, motivasi, minat, bakat, dan faktor-faktor ekstemal yang mempengaruhi prestasi belajar seorang mahasiswa. Selain itu jumlah subjek yang digunakan untuk penelitian juga ditambah, tidak hanya dari satu fakultas saja, melainkan dari berbagai macam fakultas yang ada di lingkungan UII, sehingga hasilnya lebih bisa digeneralisasikan.

Bagi Universitas Islam Indonesia sebaiknya dilakukan pengujian terhadap soal-soal yang ada sehingga dalam waktu yang akan datang soal UPCM lebih baik lagi dan dapat digunakan untuk menentukan mahasiswa yang benarbenar mempunyai potensi di bidangnya.
DAFTAR PUSTAKA

1997. Katalog Uil. Yogyakarta: UII

2002. Pedoman Umum

Penyusunan Soal UPCM Tahun 2002-2003. Yogyakarta: UII

Ahmadi, Adan Supriyono, W. 1991. Psikologi Belajar. Jakarta : Rineka Cipta.

Almigo, N. 2000. Validitas Prediksi Hasil Tes UPCm dan NEM pada Fakultas Psikologi Ull Angkatan 1997 (Lima Semester). Skripsi (Tidak Diterbitkan). Yogyakarta Fakultas Psikologi UII.

Alsa,Adan Hardjito, P. 1990. Keterkaitan Pola Belajar Siswa Kelas 6 dengan NEM yang Diperoleh. Psikologika. Fakultas Psikologi UII, Vulume 12tahun VI-2001.

Azwar, S 1996. Tes Prestasi. Yogyakarta : Pustaka Pelajar

1999. Psikologi Inteligensi. Yogyakarta : Pustaka Pelajar.

2000. Reliabilitas dan Validitas. Yogyakarta : Pustaka Pelajar.

Chaplin, J.P. 2000. Kamus Lengkap Psikologi. Jakarta : PT Raja Grafindo Persada,

Djamarah, S.B. 2002. Psikologi Belajar. Jakarta : Rineka Cipta.

Gage, N.L and Berlinger, D.C. 1998. Educational Psychology. New York: Houghton Mifflin Company. 
Hamid, E.S. 1997. Kondisi dan Tantangan Ekonomi Bangsa dalam MenyongsongAbad ke-21. Tantangan Pembangunan di Indonesia : Beberapa Pandangan Kontemporer dari Dunia Kampus. Yogyakarta : Ull Press.

Safitri, R.E. 2002. Analisis Faktor dan Daya Prediksi Tes Penerimaan Mahasiswa Baru terhadap Prestasi Belajar Mahasiswa Fakultas Teknik
Universitas Muhammadiyah

Yogyakarta. Naskah Publikasi Tesis.

Yogyakarta: Fakultas Psikologi UGM.

Setiawati, N.D.A. 2002. Kecemasan, Penyesuaian Diri dan Prestasi Belajar pada Mahasiswa Baru. Skripsi (Tidak Diterbitkan). Yogyakarta: Fakultas Psikologi Ull.

Slavin, R.E. 1991. Educational Psychology. USA: Prentice-Hal 